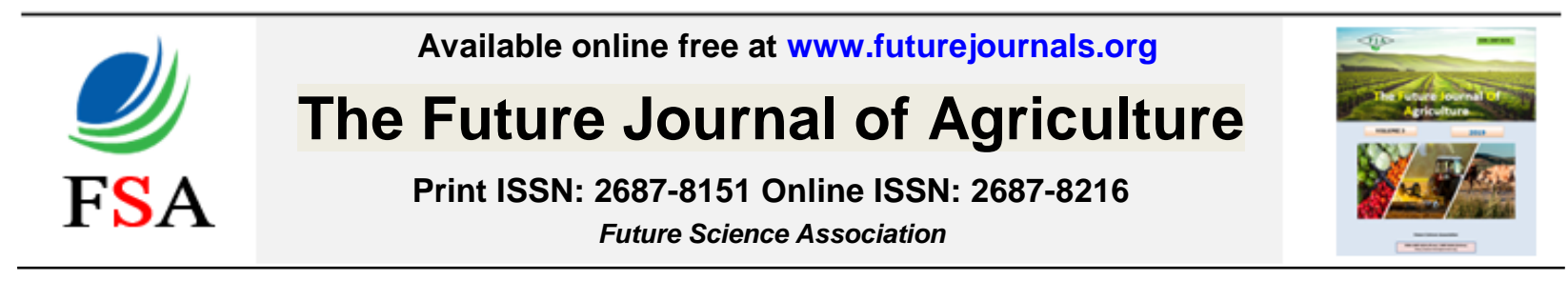

Future J. Agric., 2 (2020) 32-42

OPEN ACCES

DOI: $10.37229 /$ fsa.fja.2020.04.19

\title{
NITROGEN AND POTASSIUM NUTRIENTS REQUIREMENTS (FERTIGATION) OF ZIV CV. BANANA ON GROWTH, YIELD AND FRUIT QUALITY IN SANDY SOIL
}

\author{
Hosny S. Samia; Mahdy, H.A. and El-Kholy M.F. \\ Tropical Fruit Dept., Horticulture Research Institute, ARC, Giza, Egypt. \\ *Corresponding author: essam.1972n@yahoo.co.uk Received: 25 Mar. 2020 ; Accepted: 19 Apr. 2020
}

\begin{abstract}
The present work was done in a private farm at El-Khatatba region during three successive seasons of 2016/2017 (first ratoon), 2017/2018 (second ratoon) and 2018/2019 (third ratoon) of Ziv banana plants (Musa cavendishii L.) grown on sandy soil to study NK nutrients requirements (fertigation) on vegetative growth, yield fruit quality, NK-efficiency and economic return. Nitrogen and Potassium were applied at different rates and their combinations, Nitrogen (600g, 750 and $900 \mathrm{~g}$ actual N/plant/year) and potassium (750, 1000 and $1250 \mathrm{~g}$ actual $\mathrm{K}_{2} \mathrm{O}$ /plant/year). They were used 240 unequal doses around the year and were add as solution by fertigation. Results revealed growth parameters of plant i.e. pseudostem height, circumference, number of green leaves and assimilation area at bunch shooting stage significantly increased by increasing the rate of $\mathrm{NK}$ fertilizer. The rate of $900 \mathrm{~g}$ actual $\mathrm{N}$ and $1250 \mathrm{~g}$ actual $\mathrm{K}_{2} \mathrm{O}$ gave the highest values for the above characters compared with other treatments. Growth cycle of plants tended to decrease as fertilizers was increase. Increase the rate of fertilizers shortened the growth cycle duration of Ziv banana. The highest yield, bunch weight, finger weight and fruit characteristics were achieved from Ziv banana plants fertilized with $900 \mathrm{~g}$ actual $\mathrm{N}$ with $1250 \mathrm{~g}$ actual $\mathrm{K}_{2} \mathrm{O}$ /plant/year. $\mathrm{NK}$ utilization efficiency was affected with the rate of fertilizers. The better value of NUE $(42 \& 48 \& 44.4 \mathrm{Kg}$. fruit/g actual N) was obtained from plants fertilizer with $750 \mathrm{~g}$ actual $\mathrm{N}+1250 \mathrm{~g}$ actual $\mathrm{K}_{2} \mathrm{O}$ while highest value of KUE was (40.8 \& 48 \& 45.6) with the rate900 $\mathrm{g}$ actual $\mathrm{N}+750 \mathrm{~g}$ actual $\mathrm{K}_{2} \mathrm{O}$ under tested seasons. The economic return of $\mathrm{Ziv}$ banana plants gradually increase by increasing $\mathrm{NK}$ fertilizers. Plants were fertilized with the $900 \mathrm{~g}$. $\mathrm{N}+1250 \mathrm{~g} . \mathrm{K}_{2} \mathrm{O} /$ plant/year gave the highest income compared with other treatment. While the lowest rate of NK fertilizer $\left(600 \mathrm{~g} \mathrm{~N}+750 \mathrm{~g} \mathrm{~K}_{2} \mathrm{O}\right.$ plant/year) gave the cheap income.
\end{abstract}

Keywords: Nutrients, Ziv cv., fertigation, banana plant, productivity, yield, NUE, KUE, Economic return

\section{INTRODUCTION}

Fertigation (application of water-soluble solid or liquid fertilizer through drip irrigation system) is an attractive method of fertilization in intensive agricultural systems. Banana (Musa cavendishii L.) need and consume large amount of fertilizers from a limited soil depth, especially $\mathrm{N}$ and $\mathrm{K}$, due to its shallow root system (Amin et al., 2016). Fertilization is one of the most important factor which limiting growth and productivity in banana like all economical plant species. The high cost of intensive use of only chemical fertilizers to achieve high production of banana facing major problem for growers. nitrogen $(\mathrm{N})$ and Potassium $(\mathrm{K})$ are the most extracted macronutrients by banana plants, as they are directly related to plant growth, yield and banana fruit quality (Moreira, 1999). Potassium is the macronutrient extracted in greater amounts by banana plants (62\% of the total macronutrient and $41 \%$ of the plant nutrients), which directly affects photosynthesis, the translocation of photosynthetic and the water balance in plants and fruits (Kumar \& Kumar, 2008 and Moreira, 1999). Nitrogen acts directly on vegetative growth, emissions and the development of shoot plants and increases the amount of dry matter in plants (Moreira, 1999). Edson et al.,2017 found that the $\mathrm{N}$ and $\mathrm{K}$ fertilization levels influenced most of the phenological and production parameters of 'Grand Naine' and 'Nanicão IAC 2001'. 'Nanicão IAC 2001' and 'Grand Naine' achieved maximum yield with an application of $525 \mathrm{~kg} \mathrm{~N}$ ha-1 year-1 and 855 $\mathrm{kg} \mathrm{K}_{2} \mathrm{O}$ ha-1 year-1. 
This research aimed to identify the best fertilizer recommendation levels containing $\mathrm{N}$ and $\mathrm{K}$ and their effects on the phenological and productive characteristics of Ziv banana cultivar.

\section{MATERIAL AND METHODS}

The present work was done in a private farm at El-Khatatba region during three successive seasons of 2016/2017 $\left(1^{\text {st }}\right.$ ratoon), 2017/2018 ( $2^{\text {nd }}$ ratoon) and $2018 / 2019$ ( $3^{\text {rd }}$ ratoon) of Ziv banana plants
(Musa cavendishii L.) produced through tissue culture to study nutrients requirements (fertigation) from nitrogen and potassium on vegetative growth and yield. Banana plants were similar in growth, free of diseases, received the same horticultural managements and cultivated $3 \times 3.5$ meters apart. Soil samples from surface layer (0-30) were collected from different locations, mixed, analyzed physically and chemically according to Wilde $\boldsymbol{e t}$ al., (1985) and the data are presented in Table (1).

Table 1. Certain properties of soil used

\begin{tabular}{lccc}
\hline \multicolumn{1}{c}{ Properties } & & Depth $(\mathbf{c m})$ & $\mathbf{6 0 - 9 0}$ \\
\cline { 2 - 4 } Coarse \% & $\mathbf{0 - 3 0}$ & $\mathbf{3 0 - 6 0}$ & 64.0 \\
Fine sand \% & 51.50 & 44.60 & 22.0 \\
Silt \% & 23.0 & 28.40 & 11.0 \\
Clay \% & 15.25 & 16.50 & 3.0 \\
\hline Texture & 13.25 & 10.50 & Sandy \\
\hline Black density gm/cm & Loamy sand & Sandy & 1.70 \\
Ph & 1.56 & 1.64 & 8.4 \\
E.C.m.mhos/cm & 5.0 & 8.2 & 0.70 \\
CaCO3 & 0.53 & 0.61 & 0.78 \\
Na meg/L & 0.72 & 0.81 & 2.21 \\
K meg/L & 1.79 & 1.84 & 0.17 \\
Ca meg/L & 0.015 & 0.17 & 1.92 \\
Mg meg/L & 2.20 & 1.44 & 0.54 \\
H CO3 & 0.84 & 0.74 & 2.93 \\
Cl meg/L & 2.16 & 2.44 & 1.59 \\
SO4 meg/L & 1.74 & 1.50 & 0.74 \\
\hline
\end{tabular}

Randomized complete block design was used with 3 replicates ( 3 hools per each) in experimental seasons. Nitrogen and Potassium were applied in different rates and their combinations, Nitrogen (600, 750 and $900 \mathrm{~g}$ actual/plant) and potassium (750, 1000 and $1250 \mathrm{~g}$ actual $\mathrm{K}_{2} \mathrm{O}$ /plant) were added in the form of ammonium nitrate $\mathrm{NH}_{4} \mathrm{NO}_{3}(33.5 \%$ $\mathrm{N})$ and potassium sulphate $\left(48 \% \mathrm{~K}_{2} \mathrm{O}\right)$ respectively with the drip irrigation system. All the considered NK rates were divided into 240 doses / year applied starting with February to December for each season. (Table 2).

Table 2. Time and amount of actual NK fertigated around the year to the experimental Ziv banana plants

\begin{tabular}{lcccccc}
\hline \multirow{2}{*}{ Teat months } & \multicolumn{3}{c}{ Actual N g/ plant/ year } & \multicolumn{3}{c}{ Actual K2 O g/ plant/ year } \\
\cline { 2 - 7 } & 600 & 750 & 900 & 750 & 1000 & 1250 \\
\hline February & 30 & 38 & 45 & 22.5 & 30 & 37.5 \\
March & 35 & 43.75 & 50 & 30 & 40 & 50 \\
April & 40 & 50 & 60 & 45 & 60 & 75 \\
May & 50 & 63 & 75 & 60 & 80 & 100 \\
June & 75 & 93.75 & 100 & 75 & 100 & 125 \\
July & 80 & 100 & 120 & 105 & 140 & 175 \\
August & 80 & 100 & 120 & 112.5 & 150 & 187.5 \\
September & 85 & 105.25 & 115 & 112.5 & 150 & 187.5 \\
October & 60 & 75 & 90 & 90 & 120 & 150 \\
November & 40 & 50 & 60 & 60 & 80 & 100 \\
December & 25 & 31.25 & 35 & 37.5 & 50 & 62.5 \\
Total & 600 & 750 & 900 & 750 & 1000 & 1250 \\
\hline
\end{tabular}


Nitrogen, potassium were applied dissolved a trickle irrigation system in 20 doses / month.

\section{Data recorded}

\section{Vegetative growth parameters}

At bunch shooting stage, the following growth characteristics were recorded in three seasons: pseudostem height $(\mathrm{cm})$ as measured from the soil surface up to the petiole of the last emerged leaf, Pseudostem circumference $(\mathrm{cm})$ was measured at height of $20 \mathrm{~cm}$ above soil surface, number of green leaves per plant as well as leaf area of the $3^{\text {rd }}$ full expended leaf from the plant top was estimated using the formula of Murry (1960) (leaf area = length $\mathrm{x}$ width $x$ 0.86). Assimilation leaf area (ALA) was calculated according to Ibrahim (1993) using the formula: ALA= leaf area $\mathrm{x}$ number of leaves/ plant at bunch shooting.

\section{Flowering}

1- Time to flowering: the period from sucker emergence to bunch shooting (in days) date was calculated in the tested seasons.

2- Time to harvesting: the period from bunch shooting to date of harvesting (in days) was calculated.

3- Cropping cycle (life cycle duration): It was calculated (in days) from sucker emergence to date of harvesting

- Yield and bunch characteristics, harvesting was took place in three seasons, when the fingers reached to the full maturation. Yield (ton)/fed, bunch weight $(\mathrm{Kg})$ and finger weight $(\mathrm{g})$ were measured and recorded.

\section{- Leaf minerals content}

Leaf sample was taken from the third upper leaf (counted from the top of the plant) in each individual plant at bunch shooting stage was taken as recommended by Hewitt (1955). Leaf sample was washed by tap water then with distilled water and dried using oven at $70^{\circ} \mathrm{C}$ to a constant weight then grounded and subjected to the following determinations: the following mineral elements:

A - Total nitrogen: total $\mathrm{N}$ was determined by Micro-Kjeldahle method as described by Pregl (1945).

B- Potassium concentrations were determined by using the Atomic Absorption Spectrometer (PerkinElemer, Model 3300) according to the methods described by Chapman and Pratt (1964).
NK use efficiency was calculated according to the following equation according to Infana $e t$. al., 2015

$\mathrm{N}$ use efficiency $=$ yield $(\mathrm{kg} /$ fed. $) /$ amount of actual $\mathrm{N} /$ fed.

$\mathrm{K}$ use efficiency = yield $(\mathrm{kg} /$ fed. $) /$ amount actual $\mathrm{K}_{2} \mathrm{O} /$ fed.).

\section{Net returns}

- Total cost of fertilizers estimated using the following formula (according to Infana et. al., 2015): $\mathrm{TC}=\mathrm{TFC}+\mathrm{T} \mathrm{P} \mathrm{C}$.

- Net returns were estimated using the following formula: $\mathrm{NR}=\mathrm{TI}-\mathrm{TC}$.

\section{Statistical analysis}

Data were subjected to analysis of variance for factorial plot design in randomized complete blocks (Snedecor and Cochran 1990). Differences between treatments Means were separated by the (New L.S.D) (Waller and Duncan 1969) least significant differences test at a 0.05 probability level.

\section{RESULTS AND DISCUSSION}

\section{Vegetative growth}

Data presented in Table (3) showed that, increase nutrients significantly increased the vegetative growth of $\mathrm{Ziv}$ banana plants. The fertigation treatments induced significant differences in vegetative growth parameters at the three rates of 600, 750 and $900 \mathrm{~g}$ actual N/plant/year (299.1, 313.6 and $320.7 \mathrm{~cm})$ in the $1^{\text {st }}$ ratoon, $(303.3,318.0$ and $327.7 \mathrm{~cm})$ in the $2^{\text {nd }}$ ratoon and $(301.0,317.3$ and $327.3 \mathrm{~cm}$ ) in the $3^{\text {rd }}$ ratoon, respectively. As well as for three rates of K-fertigation (750, 1000 and 1250 $\mathrm{g}$ actual $\mathrm{K}_{2} \mathrm{O} /$ plant/year) the height values were (291, 308.5 and $333.8 \mathrm{~cm}),(295.6,313.2$ and 340.3 $\mathrm{cm})$ and $(294.6,312.9$ and $339.1 \mathrm{~cm})$ at three ratoons, respectively. Yet the pseudostem height tented to increase with increase rates of $\mathrm{NK}$ fertilizers. The highest value recorded 340, 348.5 and $347.3 \mathrm{~cm}$ with the rate of $900,1250 \mathrm{NK}$ in three tested seasons. As for the pseudostem circumference, $750 \mathrm{~g}$ actual N/plant/year significantly induced the thickest pseudostems (86.44, 90.28 and $89.39 \mathrm{~cm}$ ) throughout the three studied seasons, respectively. At the same time, $1250 \mathrm{~g}$ actual $\mathrm{K}_{2} \mathrm{O} /$ plant/ year significantly resulted in the highest circumference in the first, second and third seasons, respectively $(87.44,90.72$ and 90.00 $\mathrm{cm})$. hence, the combination $750 \mathrm{~g}$ actual $\mathrm{N}+1250$ $\mathrm{g}$ actual $\mathrm{K}_{2} \mathrm{O}$ gave the highest results (90.33, 93.6 
and $93.00 \mathrm{~cm})$. The shortest pseudostem and narrowest pseudostem circumference plants were at the lowest rate of NK $(600,750 \mathrm{~g})$ and recorded $274.2,278,271.1 \mathrm{~cm}$ and $71,74,75 \mathrm{~cm}$, respectively in three seasons. Assimilation area and number of green leaves sprout on the plant at bunch shooting stage increased with increasing rate of nutrients. The rate of $(900,1250) \mathrm{NK}$ increased the emerged green leaves $(15,14,13$ leaf/plant) and assimilation area $\left(22.9,20.9,20.9 \mathrm{~m}^{2} /\right.$ plant $)$ in comparison with the lowest rat of NK $(600,750)$ which recorded $(11,10$, 10 leaf/plant) and $\left(15,13,13.5 \mathrm{~m}^{2} /\right.$ plant $)$ in $\mathrm{Ziv}$ banana cultivar in tested seasons respectively.

The pseudostem is constituted by wrapped leaf sheaths, making it rigid, as the emergence of new leaves occurs. The proper nutrient supply furthers leaf development, and consequently, the pseudostem increases its height and diameter. Pseudostems stores large amounts of nutrients, especially $\mathrm{N}$ and $\mathrm{K}$ (67.9 and $233.1 \mathrm{~kg}$ ha-1, respectively), which is used for fruit filling.

These results are true during the three growing seasons. In this connection Loredana et al., (2015) who mentioned that growth vigor is greatly affected by soil treatment, efficiency as well as quantity and availability of nutrients. However, there is no significant effects were detected between $750,900 \mathrm{~g}$ $\mathrm{N}$ and 1000, $1250 \mathrm{~g}$ actual $\mathrm{K}_{2} \mathrm{O}$ in Pseudostem circumference through $2^{\text {nd }}$ and $3^{\text {rd }}$ seasons as well as number of green leaves/plant and assimilation area. Similarly, all interaction treatments increased height, circumference and number of leaves and leaf area of Zive banana plants grown during the three growing seasons.

The number of active leaves at blooming is an important parameter for banana bunch development because it reflects the potential yield, as these leaves are directly related to the plant photosynthetic rate (Soto-Ballestero, 2008) and promote starch accumulation in fruits.

Banana plant height and pseudostem diameter are important parameters in crop management because they are related to plant vigour and they affect bunch harvesting and breaking/tipping adult plants, consequently causing fewer losses in yield (Farias et al., 2010).

\section{Flowering}

The period from sucker emergence to bunch shooting (time to flowering), in addition, the period from bunch shooting to harvesting date were affected by the rate of $\mathrm{N}$ and $\mathrm{K}$ nutrients. Data showed significant decreases in time to flowering and harvesting compared to the other treatments. It may be recorded due to the increase in absorption of nutrient from the soil and thus promote plant growth.

Results in Table (4) show that increasing rate of $\mathrm{N}$ - fertigation gradually and significantly short ended the time to flowering. The period to flowering of plant is (414, 392, 368 days), in $1^{\text {st }}$ season (413, 389,368 days) in $2^{\text {nd }}$ season and $(412,388 \& 367$ days) in $3^{\text {rd }}$ season in $600,750,900 \mathrm{~g} \mathrm{~N} /$ plant treatments, respectively. With the effect of $\mathrm{K}-$ ferigation rates on the period to flowering, the uppermost tested rate $\left(1250 \mathrm{~g} \mathrm{~K}_{2} \mathrm{O} /\right.$ plant) shortened the period to flowering than the other treatments (377, $373 \& 370)$ days compared with (402, 404, 405 and $395,393,392$ days) for 750 and $1000 \mathrm{~g} \mathrm{~K}_{2} \mathrm{O}$ /plant/year treatments in three seasons respectively. The interaction studies between the two main factors concerning the time to flowering was statistically significant. It was clear that the combinations $(900 \mathrm{~N}+$ $1250 \mathrm{~K}_{2} \mathrm{O} /$ plant/year), was the most effective in shortening the time to flowering in three seasons.

Time to harvesting of plants was clearly decreased by increasing the rate of $\mathrm{N}$ and $\mathrm{K}$ fertilization in here seasons. In this respect manner, the interaction of $900 \mathrm{~g} N$ with $1250 \mathrm{~g}$ $\mathrm{K}_{2} \mathrm{O}$ /plant/year gave shortest period to harvesting (100, 105 and 100 days) in tested seasons, respectively.

\section{Life cycle}

Application of nitrogen at the level $900 \mathrm{~g} /$ plant markedly reduced the total duration of the crop in three tested seasons (Table 4). Applied nitrogen exerted its effect on total crop duration mainly by influencing the days to shooting. There was a reduction of $63,65,65$ days in the total crop duration when nitrogen level was increased from 600 to 900 g plant-1. Nitrogen reduced phyllochron and increased the leaf area in a short span of time thereby helping the plant to attain early physiological maturity. Thus, shooting occurred early which in turn reduced the total crop duration (Geetha, 1998 and Indira and Nair, 2008).

Potassium applied at $400 \mathrm{~g}$ plant-1 reduced duration of the crop. This might be due to the enhanced vigour of the plant and increased vegetative growth. Higher levels of potassium might have contributed much to early flowering. (Indira and Nair, 2008). 
Table 3. Effect of $\mathrm{N}$ and $\mathrm{K}$ fertigation on vegetative growth of $\mathrm{Ziv}$ banana plants at bunch shooting stage (2016/2017, 2017/2018 and 208/2019 seasons)

\begin{tabular}{|c|c|c|c|c|c|c|c|c|c|c|c|c|}
\hline \multicolumn{13}{|c|}{ Pseudostem height (cm) } \\
\hline \multirow{3}{*}{$\begin{array}{c}\text { N-fert. rate g actual / } \\
\text { plant /year }\end{array}$} & \multicolumn{4}{|c|}{ First season } & \multicolumn{4}{|c|}{ Second season } & \multicolumn{4}{|c|}{ Third season } \\
\hline & \multicolumn{12}{|c|}{$\mathrm{K}$ - fertigation rates g actual $\mathrm{K}_{2} \mathrm{O}$ /plant/year } \\
\hline & 750 & 1000 & 1250 & Mean & 750 & 1000 & 1250 & Mean & 750 & 1000 & 1250 & Mean \\
\hline 600 & 274.0 & 295.0 & 304.0 & 291 & 278.0 & 298.0 & 311.0 & 295.6 & 271.1 & 298.0 & 312.0 & 293.6 \\
\hline 750 & 296.0 & 312.0 & 318.0 & 308.5 & 300.0 & 316.0 & 324.0 & 313.2 & 301.0 & 315.0 & 323.0 & 312.9 \\
\hline 900 & 327.0 & 334.0 & 340.0 & 333.8 & 332.0 & 340.0 & 349.0 & 340.3 & 331.0 & 339.0 & 347.0 & 339.1 \\
\hline Mean & 299.0 & 314.0 & 321.0 & & 303.0 & 318.0 & 328.0 & & 301.0 & 317.0 & 327.0 & \\
\hline New L.S.D. at 0.05 & $\mathrm{~N}: 5$ & $\begin{array}{r}.976 ; \mathrm{K} \\
7 . \\
\end{array}$ & $\begin{array}{l}0.976 \\
691\end{array}$ & NK: & $\mathrm{N}: 4.09$ & $1 ; \mathrm{K}: 5$. & $091 ; \mathrm{NK}$ & 6.889 & $\mathrm{~N}: 5.00$ & $8 ; \mathrm{K}: 5.0$ & $08 ; \mathrm{NK}$ & : 6.747 \\
\hline \multicolumn{13}{|c|}{ Pseudostem circumference $(\mathrm{cm})$} \\
\hline \multirow{3}{*}{$\begin{array}{c}\mathrm{N} \text {-fert. rate g actual / } \\
\text { plant /year }\end{array}$} & \multicolumn{4}{|c|}{ First season } & \multicolumn{4}{|c|}{ Second season } & \multicolumn{4}{|c|}{ Third season } \\
\hline & \multicolumn{12}{|c|}{$\mathrm{K}$ - fertigation rates g actual $\mathrm{K}_{2} \mathrm{O}$ /plant/year } \\
\hline & 750 & 1000 & 1250 & Mean & 750 & 1000 & 1250 & Mean & 750 & 1000 & 1250 & Mean \\
\hline 600 & 71.00 & 82.00 & 83.00 & 78.70 & 74.00 & 87.70 & 87.00 & 82.89 & 75.00 & 85.50 & 86.00 & 82.17 \\
\hline 750 & 83.00 & 86.00 & 90.3 & 86.44 & 87.70 & 89.50 & 93.70 & 90.28 & 86.67 & 88.50 & 93.00 & 89.39 \\
\hline 900 & 85.00 & 87.00 & 89.0 & 87.0 & 88.00 & 90.00 & 91.50 & 89.33 & 87.50 & 89.00 & 91.00 & 89.17 \\
\hline Mean & 79.70 & 85.20 & 87.40 & & 83.20 & 89.10 & 90.70 & & 83.06 & 87.70 & 90.00 & \\
\hline
\end{tabular}

New L.S.D. at 0.05 N:1.479; K:2.479; NK: 2.829 N:1.438; K:2.438; NK: 2.758 N:1.503; K:1.503; NK: 2.871

\begin{tabular}{|c|c|c|c|c|c|c|c|c|c|c|c|c|}
\hline \multicolumn{13}{|c|}{ Assimilation area $\left(\mathbf{m}^{2}\right)$} \\
\hline \multirow{3}{*}{$\begin{array}{l}\text { N-fert. rate g actual / } \\
\text { plant /year }\end{array}$} & \multicolumn{4}{|c|}{ First season } & \multicolumn{4}{|c|}{ Second season } & \multicolumn{4}{|c|}{ Third season } \\
\hline & \multicolumn{12}{|c|}{$\mathrm{K}$ - fertigation rates g actual $\mathrm{K}_{2} \mathrm{O}$ /plant/year } \\
\hline & $\mathbf{7 5 0}$ & 1000 & 1250 & Mean & 750 & 1000 & 1250 & Mean & $\mathbf{7 5 0}$ & 1000 & 1250 & Mean \\
\hline 600 & 15.0 & 16.2 & 17.8 & 16.3 & 13.0 & 15.0 & 16.7 & 14.9 & 13.5 & 16.0 & 17.0 & 15.5 \\
\hline 750 & 18.9 & 18.2 & 18.9 & 18.7 & 16.5 & 18.0 & 16.5 & 17.0 & 17.1 & 19.0 & 18.5 & 18.2 \\
\hline 900 & 20.7 & 21.7 & 22.9 & 21.8 & 17.8 & 20.1 & 20.9 & 19.6 & 18.2 & 20.2 & 20.9 & 19.8 \\
\hline Mean & 18.2 & 18.7 & 19.9 & & 15.8 & 17.7 & 18.0 & & 16.3 & 18.4 & 18.8 & \\
\hline New L.S.D. at 0.05 & \multicolumn{4}{|c|}{$\begin{array}{c}\mathrm{N}: 0.694 ; \mathrm{K}: 0.694 ; \mathrm{NK}: \\
1.202 \\
\end{array}$} & \multicolumn{4}{|c|}{$\begin{array}{c}\mathrm{N}: 0.611 ; \mathrm{K}: \mathrm{N} . \mathrm{S} . ; \mathrm{NK}: \\
0.1 .059\end{array}$} & \multicolumn{4}{|c|}{ N: 0.694; K: 0.694; NK: 1.202} \\
\hline \multicolumn{13}{|c|}{ Number of green leaves/plant } \\
\hline \multirow{3}{*}{$\begin{array}{l}\mathrm{N} \text {-fert. rate g actual / } \\
\text { plant /year }\end{array}$} & \multicolumn{4}{|c|}{ First season } & \multicolumn{4}{|c|}{ Second season } & \multicolumn{4}{|c|}{ Third season } \\
\hline & \multicolumn{12}{|c|}{$\mathrm{K}$ - fertigation rates g actual $\mathrm{K}_{2} \mathrm{O} /$ plant/year } \\
\hline & 750 & 1000 & 1250 & Mean & 750 & 1000 & 1250 & Mean & 750 & 1000 & 1250 & Mean \\
\hline 600 & 11.0 & 12.0 & 13.0 & 12.0 & 10.0 & 11.0 & 12.0 & 11.0 & 10.0 & 11.0 & 12.0 & 11.0 \\
\hline 750 & 13.0 & 13.0 & 14.0 & 13.3 & 12.0 & 13.0 & 14.0 & 13.0 & 11.0 & 12.0 & 13.0 & 12.0 \\
\hline 900 & 14.0 & 14.0 & 15.0 & 14.3 & 13.0 & 14.0 & 14.0 & 13.7 & 12.0 & 13.0 & 13.0 & 12.7 \\
\hline Mean & 12.7 & 13.0 & 14.0 & & 11.7 & 12.7 & 13.3 & & 11.0 & 12.0 & 12.7 & \\
\hline
\end{tabular}

New L.S.D. at 0.05 N: 0.626; K: 0.626; NK: N.S. N: 0.577; K: N.S.; NK: N.S. N: 0.577; K: N.S.; NK: N.S. 
Hosny S. Samia et al.

Table 4. Effect of $\mathrm{N}$ and $\mathrm{K}$ fertigation on flowering time, harvesting time and crop duration of Ziv banana plants at bunch shooting stage (2016/2017, 2017/2018 and 208/2019 seasons)

\begin{tabular}{|c|c|c|c|c|c|c|c|c|c|c|c|c|}
\hline \multicolumn{13}{|c|}{ Flowering time (days) } \\
\hline \multirow{3}{*}{$\begin{array}{c}\mathrm{N} \text {-fert. rate g } \\
\text { actual/plant/year }\end{array}$} & \multicolumn{4}{|c|}{ First season } & \multicolumn{4}{|c|}{ Second season } & \multicolumn{4}{|c|}{ Third season } \\
\hline & \multicolumn{12}{|c|}{$\mathrm{K}$ - fertigation rates g actual $\mathrm{K}_{2} \mathrm{O}$ /plant/year } \\
\hline & 750 & 1000 & 1250 & Mean & $\mathbf{7 5 0}$ & 1000 & 1250 & Mean & 750 & 1000 & 1250 & Mean \\
\hline 600 & 427 & 415 & 401 & 414 & 428 & 413 & 398 & 413 & 427 & 415 & 395 & 412 \\
\hline 750 & 403 & 398 & 375 & 392 & 401 & 392 & 374 & 389 & 403 & 390 & 370 & 388 \\
\hline 900 & 377 & 373 & 354 & 368 & 382 & 373 & 348 & 368 & 384 & 371 & 346 & 367 \\
\hline Mean & 402 & 395 & 377 & & 404 & 393 & 373 & & 405 & 392 & 370 & \\
\hline
\end{tabular}

New L.S.D. at 0.05 N: 5.856; K:3.856; NK: 6.214

N: 5.119; K: 6.119; NK: 9.938

N: 5.209; K: 5.209; NK: 6.094

Harvesting time (days)

\begin{tabular}{|c|c|c|c|c|c|c|c|c|c|c|c|c|}
\hline \multirow{3}{*}{$\begin{array}{l}\mathrm{N} \text {-fert. rate g } \\
\text { actual/plant/year }\end{array}$} & \multicolumn{4}{|c|}{ First season } & \multicolumn{4}{|c|}{ Second season } & \multicolumn{4}{|c|}{ Third season } \\
\hline & \multicolumn{12}{|c|}{$\mathrm{K}$ - fertigation rates g actual $\mathrm{K}_{2} \mathrm{O} /$ plant/year } \\
\hline & 750 & 1000 & 1250 & Mean & 750 & 1000 & 1250 & Mean & 750 & 1000 & 1250 & Mean \\
\hline 600 & 130 & 120 & 115 & 122 & 140 & 130 & 125 & 132 & 130 & 120 & 110 & 120 \\
\hline 750 & 120 & 115 & 105 & 113 & 130 & 120 & 115 & 122 & 120 & 110 & 100 & 110 \\
\hline 900 & 110 & 105 & 100 & 105 & 120 & 110 & 105 & 112 & 100 & 100 & 100 & 100 \\
\hline Mean & 120 & 113 & 107 & & 130 & 120 & 115 & & 117 & 110 & 103 & \\
\hline
\end{tabular}

New L.S.D. at 0.05 N: 1.549; K: 1.549; NK: 2.684N: 1.332; K:1.332; NK: 2.307N: 1.521; K: 1.521; NK: 2.635

\begin{tabular}{|c|c|c|c|c|c|c|c|c|c|c|c|c|}
\hline \multicolumn{13}{|c|}{ Life cycle } \\
\hline \multirow{3}{*}{$\begin{array}{l}\mathrm{N} \text {-fert. rate } \mathrm{g} \\
\text { actual/plant/year }\end{array}$} & \multicolumn{4}{|c|}{ First season } & \multicolumn{4}{|c|}{ Second season } & \multicolumn{4}{|c|}{ Third season } \\
\hline & \multicolumn{12}{|c|}{$\mathrm{K}-$ fertigation rates g actual $\mathrm{K}_{2} \mathrm{O} /$ plant/year } \\
\hline & 750 & 1000 & 1250 & Mean & 750 & 1000 & 1250 & Mean & 750 & 1000 & 1250 & Mean \\
\hline 600 & 557 & 535 & 516 & 536 & 568 & 543 & 523 & 545 & 557 & 535 & 505 & 532 \\
\hline 750 & 523 & 513 & 480 & 505 & 531 & 512 & 489 & 511 & 523 & 500 & 470 & 498 \\
\hline 900 & 487 & 478 & 454 & 473 & 502 & 483 & 453 & 479 & 484 & 471 & 446 & 467 \\
\hline Mean & 522 & 509 & 483 & & 527 & 513 & 488 & & 521 & 502 & 474 & \\
\hline
\end{tabular}

New L.S.D. at 0.05 N: 7.068; K: 7.068; NK: $9.582 \quad$ N: 6.043; K: 6.043; NK: $\quad$ N: 8.938; K: 8.938; NK: 9.357

\section{Chemical constituents of the leaves}

Data presented in Table (5) show that $\mathrm{N}$ concentration in leaf of fertilized plants increased by increasing rate of $\mathrm{N}$-fertigation in the three tested seasons. The highest values of $\mathrm{N}$ concentration were show with 750 and $900 \mathrm{~g} \mathrm{~N} /$ plant/year. Concerning of K-concentration data tended to decreased with increasing rate of $\mathrm{N}$-fertigation. $\mathrm{NK}$-concentration were $(2.58,3.01,3.18 \& 2.53,2.93,3.33 \& 2.27$, $2.36 \& 2.81 \%)$ and $(3.37,3.17,3.03 \& 3.69,3.47$, $3.33 \& 3.63,3.42,3.33 \%$ in treatments of 600,750 , $900 \mathrm{~g} \mathrm{~N} /$ plant/year in three tested seasons for Leaf $\mathrm{N}$ and $\mathrm{K}$ contents. $\mathrm{K}$-concentration in $\mathrm{Ziv}$ banana leaves tended to increase as $\mathrm{K}$-fertigation rates were increased. The greatest values of $\mathrm{K}$ concentration in the leaves were noticed with $1250 \mathrm{~g} \mathrm{~K}_{2} \mathrm{O}$ /plant/year $(3.67,4.0,4.0 \%)$ respectively, However, low rate of $\mathrm{K}$-fertigation (750g $\mathrm{K}_{2} \mathrm{O} /$ plant/year) minimized the K concentration $(2.67,3.1,3.09 \%)$ than other tested treatment in three seasons respectively. Interaction showed significant differences between $\mathrm{N}$ and $\mathrm{K}$ rates which leaf $\mathrm{K}$ content in response to $\mathrm{N}$ and $\mathrm{K}$ fertigation. These results harmony with Ibrahim (2003) and Hosny (2010) on banana plants where noticed that adding chemical fertilizers particularly NPK enhance chemical activities and N, P and K releasing thereby increased these elements in rooting zone, consequently increasing their absorption by the plant. By these possibilities, the concentration of NK in the root zone increased which encouraged NK absorption and consequently its accumulation in leaves. 
Hosny S. Samia et al.

Table 5. Effect of $\mathrm{N}$ and $\mathrm{K}$ fertigation on chemical constituents of the leaves of Ziv banana plants at bunch shooting stage $(2016 / 2017,2017 / 2018$ and 208/2019 seasons)

\begin{tabular}{|c|c|c|c|c|c|c|c|c|c|c|c|c|}
\hline \multicolumn{13}{|c|}{ Leaf $N$ content $(\%)$} \\
\hline \multirow{3}{*}{$\begin{array}{c}\mathrm{N} \text {-fert. rate g } \\
\text { actual/plant /year }\end{array}$} & \multicolumn{4}{|c|}{ First season } & \multicolumn{4}{|c|}{ Second season } & \multicolumn{4}{|c|}{ Third season } \\
\hline & \multicolumn{12}{|c|}{$\mathrm{K}$ - fertigation rates g actual $\mathrm{K}_{2} \mathrm{O} /$ plant/year } \\
\hline & 750 & 1000 & 1250 & Mean & 750 & 1000 & 1250 & Mean & 750 & 1000 & 1250 & Mean \\
\hline 600 & 2.81 & 2.61 & 2.31 & 2.58 & 2.74 & 2.54 & 2.31 & 2.53 & 2.41 & 2.20 & 2.20 & 2.27 \\
\hline 750 & 3.11 & 3.01 & 2.91 & 3.01 & 3.04 & 2.91 & 2.85 & 2.93 & 2.59 & 2.30 & 2.20 & 2.36 \\
\hline 900 & 3.25 & 3.10 & 3.30 & 3.18 & 3.10 & 3.00 & 3.90 & 3.33 & 2.62 & 2.50 & 3.30 & 2.81 \\
\hline Mean & 3.06 & 2.91 & 2.84 & & 2.96 & 2.82 & 3.02 & & 2.54 & 2.33 & 2.57 & \\
\hline New L.S.D. at 0.05 & \multicolumn{4}{|c|}{$\begin{array}{c}\mathrm{N}: 0.314 ; \mathrm{K}: 0.314 ; \mathrm{NK}: \\
0.544\end{array}$} & \multicolumn{8}{|c|}{ N: $0.303 ; \mathrm{K}: \mathrm{N}, \mathrm{S} . ; \mathrm{NK}: 0.525 \mathrm{~N}: 0.134 ; \mathrm{K}: 0.134 ; \mathrm{NK}: 0.231$} \\
\hline \multicolumn{13}{|c|}{ Leaf $K$ content $(\%)$} \\
\hline \multirow{3}{*}{$\begin{array}{c}\text { N-fert. rate g } \\
\text { actual/plant /year }\end{array}$} & \multicolumn{4}{|c|}{ First season } & \multicolumn{4}{|c|}{ Second season } & \multicolumn{4}{|c|}{ Third season } \\
\hline & \multicolumn{12}{|c|}{$\mathrm{K}$ - fertigation rates g actual $\mathrm{K}_{2} \mathrm{O}$ /plant/year } \\
\hline & 750 & 1000 & 1250 & Mean & 750 & 1000 & 1250 & Mean & 750 & 1000 & 1250 & Mean \\
\hline 600 & 2.81 & 3.39 & 3.90 & 3.37 & 3.30 & 3.68 & 4.10 & 3.69 & 3.20 & 3.60 & 4.10 & 3.63 \\
\hline 750 & 2.70 & 3.20 & 3.60 & 3.17 & 3.10 & 3.30 & 4.00 & 3.47 & 3.06 & 3.20 & 4.00 & 3.42 \\
\hline 900 & 2.50 & 3.10 & 3.50 & 3.03 & 2.90 & 3.20 & 3.90 & 3.33 & 3.00 & 3.10 & 3.90 & 3.33 \\
\hline Mean & 2.67 & 3.23 & 3.67 & & 3.10 & 3.39 & 4.00 & & 3.09 & 3.30 & 4.00 & \\
\hline New L.S.D. at 0.05 & & $\begin{array}{r}.210 ; \mathrm{K} \\
0 .\end{array}$ & 0.210 & NK: & $\mathrm{N}: 0.09$ & $7 ; \mathrm{K}: 0.0$ & $97 ; \mathrm{NK}$ & x: 0.168 & $\mathrm{~N}: 0.14$ & 0; K:0.1 & $40 ; \mathrm{NK}$ & 0.243 \\
\hline
\end{tabular}

\section{Bunch weight and yield}

As for yield and its components, data in Table (6) show that plants fertilized with the highest doses from $\mathrm{N}$ and $\mathrm{K}$ significantly increased bunch and finger weight as well as yield in three seasons. This increase in weight may be attributed to an increase in cell division and elongation which caused an induction of vegetative growth, favoring physiological processes reflected on increasing yield and its components. Similar results were concluded (Jothimani et al., 2013). Finger weight/bunch, bunch weight/plant and yield/Fed. significantly varied according to the $\mathrm{N}$ and $\mathrm{k}$ fertigation. All interaction treatments increased these parameters and showed an additive effect in this respect. The heaviest bunches, (or yield/ Fed.), finger/plant were produced in plants received the rate of 900 and 1250 $\mathrm{g} /$ plant/year NK treatment were $(44 \& 47 \& 46$ kg/plant., 34.83 \& 42.3 \& 41.4ton/fed., 254.9 \& $266.4 \& 260 \mathrm{~g} /$ fruit.) on three tested seasons, and the lightest bunches(or yield/Fed.), fingers/plants were obtained from the plants fertilized with lowest NK doses $(600,750 \mathrm{NK}$ g/plant/year) treatment were $(20$ \& $25 \& 18 \mathrm{~kg}, 18 \& 22.5 \& 16.2$ ton /fed. $121.2 \&$ $154.8 \& 109 \mathrm{~g} /$ fruit).

Concerning increasing rate of yield results show significantly varied according to increase in NK- fertigation. Treatment $900 \mathrm{~g}$ actual $\mathrm{N}+1250 \mathrm{~g}$ actual $\mathrm{K}_{2} \mathrm{O}$ recorded the highest percentage of $(48.2,45.8,61.3 \%)$ compared with the other treatment in the tested seasons. The increase in fruit weight might be due to the removal of flower bud after formation of the bunch which helped in conservation and utilization of photosynthetic in the more efficient way. Potassium improves fruit weight and number of fingers per bunch, and increases the content of starch and sugar content (Bhargava et al., 1993). Also, Pandey and Sinha (1999) who reported that the increase in weight of the hand, weight of the bunch and yield per hectare are due to sulphur present in the sulphate of potash which might be responsible for the formation of ironsulphur protein in plants which might have a direct impact in activating the catalase and peroxidase enzymes. Moreover, the increase in bunch weight can be attributed to the cumulative effect of yield attributing characters like finger weight, length of the finger, circumference of the finger and pulp to peel ratio. The favourable influence of $\mathrm{K}_{2} \mathrm{SO}_{4}$ as compared to other nutrients on the production of heavier bunches might be attributed to the heavier dry matter and starch accumulation and additionally promoted by the sulphur present in $\mathrm{K}_{2} \mathrm{SO}_{4}$ (Kumar and Kumar, 2008). 
Table 6. Effect of $\mathrm{N}$ and $\mathrm{K}$ fertigation on bunch weight $(\mathrm{kg})$, yield(ton), finger weight (g) and Increasing rate of yield (\%) of Ziv banana plants at (2016/2017, 2017/2018 and 208/2019 seasons)

\begin{tabular}{|c|c|c|c|c|c|c|c|c|c|c|c|c|}
\hline \multicolumn{13}{|c|}{ Finger weight (g) } \\
\hline \multirow{3}{*}{$\begin{array}{l}\mathrm{N} \text {-fert. rate g actual / } \\
\text { plant /year }\end{array}$} & \multicolumn{4}{|c|}{ First season } & \multicolumn{4}{|c|}{ Second season } & \multicolumn{4}{|c|}{ Third season } \\
\hline & \multicolumn{12}{|c|}{$\mathrm{K}$ - fertigation rates g actual $\mathrm{K}_{2} \mathrm{O} /$ plant/year } \\
\hline & 750 & 1000 & 1250 & Mean & 750 & 1000 & 1250 & Mean & $\mathbf{7 5 0}$ & 1000 & 1250 & Mean \\
\hline 600 & 121.1 & 151.6 & 191.4 & 154.7 & 154.8 & 185.2 & 196.5 & 178.8 & 109.0 & 130.4 & 179.0 & 139.5 \\
\hline 750 & 163.7 & 196.0 & 201.2 & 187.0 & 193.5 & 216.0 & 217.4 & 209.0 & 169.0 & 180.5 & 201.0 & 183.5 \\
\hline 900 & 188.9 & 224.9 & 254.6 & 222.8 & 222.2 & 233.9 & 266.4 & 240.8 & 206.4 & 227.8 & 260.0 & 231.4 \\
\hline Mean & 157.9 & 190.8 & 215.7 & & 190.2 & 211.7 & 226.8 & & 161.5 & 179.6 & 213.3 & \\
\hline New L.S.D. at 0.05 & \multicolumn{4}{|c|}{$\begin{array}{c}\mathrm{N}: 3.765 ; \mathrm{K}: 3.765 ; \mathrm{NK}: \\
6.522 \\
\end{array}$} & \multicolumn{4}{|c|}{$\begin{array}{c}\mathrm{N}: 3.295 ; \mathrm{K}: 3.295 ; \mathrm{NK}: \\
5.706\end{array}$} & \multicolumn{4}{|c|}{$\mathrm{N}: 3.414 ; \mathrm{K}: 3.414 ; \mathrm{NK}: 5.912$} \\
\hline \multicolumn{13}{|c|}{ Bunch weight (Kg) } \\
\hline \multirow{3}{*}{$\begin{array}{c}\mathrm{N} \text {-fert. rate g actual / } \\
\text { plant /year }\end{array}$} & \multicolumn{4}{|c|}{ First season } & \multicolumn{4}{|c|}{ Second season } & \multicolumn{4}{|c|}{ Third season } \\
\hline & \multicolumn{12}{|c|}{$\mathrm{K}$ - fertigation rates g actual $\mathrm{K}_{2} \mathrm{O} /$ plant/year } \\
\hline & $\mathbf{7 5 0}$ & 1000 & 1250 & Mean & 750 & 1000 & 1250 & Mean & 750 & 1000 & 1250 & Mean \\
\hline 600 & 20.0 & 28.0 & 31.0 & 26.3 & 25.0 & 30.0 & 32.0 & 29.0 & 18.0 & 21.0 & 29.0 & 22.7 \\
\hline 750 & 28.0 & 32.0 & 35.0 & 31.7 & 34.0 & 38.0 & 40.0 & 37.3 & 32.0 & 34.0 & 37.0 & 34.3 \\
\hline 900 & 34.0 & 38.0 & 44.0 & 38.7 & 40.0 & 43.0 & 47.0 & 43.3 & 38.0 & 41.0 & 46.0 & 41.7 \\
\hline Mean & 27.3 & 32.7 & 36.7 & & 33.0 & 37.0 & 39.7 & & 29.3 & 32 & 37.3 & \\
\hline New L.S.D. at 0.05 & \multicolumn{4}{|c|}{$\begin{array}{c}\mathrm{N}: 0.421 ; \mathrm{K}: 0.421 ; \mathrm{NK} \\
0.730\end{array}$} & \multicolumn{4}{|c|}{$\begin{array}{c}\mathrm{N}: 0.353 ; \mathrm{K}: 0.353 ; \mathrm{NK}: \\
0.612\end{array}$} & \multicolumn{4}{|c|}{$\begin{array}{c}\mathrm{N}: 0.421 ; \mathrm{K}: 0.421 ; \mathrm{NK}: \\
0.730\end{array}$} \\
\hline \multicolumn{13}{|c|}{ Yield/Fed. (ton) } \\
\hline \multirow{3}{*}{$\begin{array}{c}\mathrm{N} \text {-fert. rate g actual / } \\
\text { plant /year }\end{array}$} & \multicolumn{4}{|c|}{ First season } & \multicolumn{4}{|c|}{ Second season } & \multicolumn{4}{|c|}{ Third season } \\
\hline & \multicolumn{12}{|c|}{$\mathrm{K}$ - fertigation rates g actual $\mathrm{K}_{2} \mathrm{O}$ /plant/year } \\
\hline & 750 & 1000 & 1250 & Mean & 750 & 1000 & 1250 & Mean & 750 & 1000 & 1250 & Mean \\
\hline 600 & 18.0 & 25.2 & 27.9 & 23.7 & 22.5 & 27.0 & 28.8 & 26.1 & 16.2 & 18.9 & 26.1 & 20.4 \\
\hline 750 & 25.2 & 28.8 & 31.5 & 28.5 & 30.6 & 34.2 & 36.0 & 33.6 & 28.8 & 30.6 & 33.3 & 30.9 \\
\hline 900 & 30.6 & 34.2 & 34.83 & 33.2 & 36.0 & 38.7 & 42.3 & 39.0 & 34.2 & 36.9 & 41.4 & 37.5 \\
\hline Mean & 24.6 & 29.4 & 31.4 & & 29.7 & 33.3 & 35.7 & & 26.4 & 28.8 & 33.6 & \\
\hline New L.S.D. at 0.05 & & $\begin{array}{r}300 ; \mathrm{K}: \\
0.5\end{array}$ & $\begin{array}{l}0.300 \\
20\end{array}$ & NK: & $\mathrm{N}: 0$ & $\begin{array}{r}.281 ; \mathrm{K} \\
0.4 \\
\end{array}$ & $\begin{array}{l}0.281 \\
886\end{array}$ & NK: & N 0.300 & ; K: 0.3 & $00 ; \mathrm{NK}$ & 0.520 \\
\hline \multicolumn{13}{|c|}{ Increasing rate of yield $(\%)$} \\
\hline & & First & eason & & & Second & season & & & Third s & eason & \\
\hline $\begin{array}{l}\text { N-fert. rate g actual/ } \\
\text { plant / year }\end{array}$ & & & & $K$ - fert & igation & rates $\mathrm{g}$ & actual & $\mathrm{K}_{2} \mathrm{O} / \mathrm{p}$ & lant/yea & & & \\
\hline & 750 & 1000 & 1250 & Mean & 750 & 1000 & 1250 & Mean & 750 & 1000 & 1250 & Mean \\
\hline 600 & 0.0 & 28.5 & 35.5 & 21.3 & 0.0 & 16.7 & 21.9 & 12.9 & 0.0 & 14.3 & 37.9 & 17.4 \\
\hline 750 & 28.5 & 37.5 & 42.9 & 36.3 & 26.5 & 34.2 & 37.5 & 32.7 & 43.8 & 47.1 & 51.4 & 47.4 \\
\hline 900 & 41.2 & 47.4 & 48.2 & 45.6 & 37.5 & 41.8 & 45.8 & 41.7 & 52.6 & 56.1 & 61.3 & 56.7 \\
\hline Mean & 23.2 & 37.8 & 42.2 & & 21.3 & 30.9 & 35.1 & & 32.1 & 39.2 & 50.2 & \\
\hline New L.S.D. at 0.05 & $\mathrm{~N}: 3$ & $\begin{array}{r}.092 ; \mathrm{K} \\
5.1\end{array}$ & $\begin{array}{l}4.092 \\
59\end{array}$ & ; NK: & $\mathrm{N}: 3$ & $\begin{array}{r}.081 ; \mathrm{K} \\
6.1 \\
\end{array}$ & $\begin{array}{l}: 4.081 \\
140\end{array}$ & ; NK: & $\mathrm{N}: 6$. & $\begin{array}{r}092 ; \mathrm{K}: \\
9.1\end{array}$ & $\begin{array}{l}7.092 ; \\
59\end{array}$ & \\
\hline
\end{tabular}


Nitrogen use efficiency (Kg. fruits/one $\mathrm{Kg} \mathrm{N}$ fertilizer)

Results in Table (7) obtained that nitrogen or Potassium use efficiency (NUE) or (KUE), is expressed as the amount of Grand Nain banana fruits in $\mathrm{Kg}$. that could be produced from one $\mathrm{kg}$. of $\mathrm{N}$ or $\mathrm{K}$ actual fertilizer. NUE and KUE clearly affected by fertilizer. The results show that the highest value of NUE was $(38,44.7,41.2 \mathrm{~kg}$ fruit $/ \mathrm{kg}$ fertilizer) with the rate of $(750 \mathrm{~g}$ actual $\mathrm{N} /$ plant/year) while, in the KUE results recorded highest value $(41.8 \& 47.8 \& 41.6)$ at the rate $1250 \mathrm{~g}$ actual $\mathrm{K}_{2} \mathrm{O}$ /plant/year). In other words, $\mathrm{N}$-use efficiency increased with increasing potassium fertilizers while K-use efficiency increased with increasing nitrogen fertilizers. These results agree with Jaime et al., (2017) whose reported that high dose of nitrogen showed a trend to increase the nutrients accumulation during the banana plant development but especially, until fructification stage, with the exception of $\mathrm{Mg}$ and $\mathrm{Ca}$, which achieved the greatest accumulation in harvest timing. Studies on fruit crops showed that use efficiency of $\mathrm{N}, \mathrm{P}$, and $\mathrm{K}$ fertilizers were negatively correlated with the fertilizer rates (Zhang et al., 2010 and Quaggio et al., 2019). Overall, a rational nutrient management is therefore even more crucial for balancing yield and environmental concern in countries like China, India and other countries where fertilizers are generally overused (Wenli et. al.,2020).

Table 7. Effect of $\mathrm{N}$ and $\mathrm{K}$ fertigation on NK use efficiency of the leaves of Ziv banana plants at bunch shooting stage $(2016 / 2017,2017 / 2018$ and $208 / 2019$ seasons $)$

\begin{tabular}{|c|c|c|c|c|c|c|c|c|c|c|c|c|}
\hline \multicolumn{13}{|c|}{$\mathbf{N}$ use efficiency } \\
\hline \multirow{3}{*}{$\begin{array}{l}\text { N-fert. rate g actual/ } \\
\text { plant /year }\end{array}$} & \multicolumn{4}{|c|}{ First season } & \multicolumn{4}{|c|}{ Second season } & \multicolumn{4}{|c|}{ Third season } \\
\hline & \multicolumn{12}{|c|}{$\mathrm{K}-$ fertigation rates g actual. $\mathrm{K}_{2} \mathrm{O} /$ plant/year } \\
\hline & 750 & 1000 & 1250 & Mean & 750 & 1000 & 1250 & Mean & 750 & 1000 & 1250 & Mean \\
\hline 600 & 30.0 & 33.6 & 46.5 & 36.7 & 37.5 & 45.0 & 48.0 & 43.5 & 27.0 & 31.5 & 34.5 & 31.0 \\
\hline 750 & 33.6 & 38.4 & 42.0 & 38.0 & 40.5 & 45.6 & 48.0 & 44.7 & 38.4 & 40.8 & 44.4 & 41.2 \\
\hline 900 & 34.0 & 38.0 & 36.9 & 36.3 & 40.0 & 43.0 & 47.3 & 43.4 & 38.0 & 41.0 & 46.0 & 41.7 \\
\hline Mean & 32.5 & 36.7 & 41.8 & & 39.3 & 44.5 & 47.8 & & 34.5 & 37.8 & 41.6 & \\
\hline New L.S.D. at 0.05 & \multicolumn{4}{|c|}{$\mathrm{N}: 3.14 ; \mathrm{K}: 3.01 ; \mathrm{NK}: 4.73$} & \multicolumn{4}{|c|}{$\mathrm{N}: 6.45 ; \mathrm{K}: \mathrm{N}, \mathrm{S} ; \mathrm{NK}: 5.34$} & \multicolumn{4}{|c|}{$\mathrm{N}: 3.05 ; \mathrm{K}: 3.05 ; \mathrm{NK}: 3.80$} \\
\hline \multicolumn{13}{|c|}{ K use efficiency } \\
\hline \multirow{3}{*}{$\begin{array}{l}\mathrm{N} \text {-fert. rate g actual/ } \\
\text { plant /year }\end{array}$} & \multicolumn{4}{|c|}{ First season } & \multicolumn{4}{|c|}{ Second season } & \multicolumn{4}{|c|}{ Third season } \\
\hline & \multicolumn{12}{|c|}{$\mathrm{K}-$ fertigation rates g actual $\mathrm{K}_{2} \mathrm{O} /$ plant/year } \\
\hline & 750 & 1000 & 1250 & Mean & 750 & 1000 & 1250 & Mean & 750 & 1000 & 1250 & Mean \\
\hline 600 & 24.0 & 25.2 & 22.3 & 23.8 & 30.0 & 27.0 & 23.0 & 26.7 & 21.6 & 18.9 & 20.9 & 20.5 \\
\hline 750 & 33.6 & 28.8 & 25.2 & 29.2 & 40.8 & 34.2 & 28.8 & 34.6 & 38.4 & 30.6 & 26.6 & 31.9 \\
\hline 900 & 40.8 & 34.2 & 27.9 & 34.3 & 48.0 & 38.7 & $33 . .8$ & 43.4 & 45.6 & 36.9 & 33.1 & 38.5 \\
\hline Mean & 32.8 & 29.4 & 25.1 & & 39.6 & 33.3 & 25.9 & & 35.2 & 28.8 & 26.9 & \\
\hline New L.S.D. at 0.05 & \multicolumn{4}{|c|}{$\mathrm{N}: 3.29 ; \mathrm{K} 3.29 ; \mathrm{NK}: 3.72$} & \multicolumn{4}{|c|}{$\mathrm{N}: 4.71 ; \mathrm{K}: 4.71 ; \mathrm{NK}: 4.3$} & \multicolumn{4}{|c|}{$\mathrm{N}: 2.3 ; \mathrm{K}: 2.3 ; \mathrm{NK}: 3.1$} \\
\hline
\end{tabular}

\section{Fruit physical properties}

Finger length and diameter $(\mathrm{cm})$ data presented in Table (8) revealed that, the values of finger length recorded by $14.6,17.7,18.2$ in $1^{\text {st }}$ season; $18.9,21.1,21.1$ in the $2^{\text {nd }}$ season and $18.7,20.8,21$ in $3^{\text {rd }}$ season, respectively for $\mathrm{N}$ fertigation rates $\mathrm{gm} /$ plant. Furthermore, the interaction effect between NK gave the highest values $(21.60,21.84$, $21.72 \mathrm{~cm}$ ) in finger parameters recorded by 900 and 1250 in three tested seasons. Contrary, to the low doses fertigation for (600 plus 750) recorded the lowest values through three tested seasons.

Data tabulated in Table (6) obviously that, the highest values of finger diameter $(3.28,3.30$ and 3.33) for $\mathrm{N}$ fertigation rates $\mathrm{gm} / \mathrm{plant}$, in first; second and third seasons, respectively. Moreover, the interaction effect between NK gave the highest values (3.30 and $3.42 \mathrm{~cm}) ;(3.31$ and 3.43$)$ in finger parameters recorded by $900 ; 1000$ and 1250 for $1^{\text {st }}$ and $2^{\text {nd }}$ season; while the $3^{\text {rd }}$ season give $750 ; 900$ and 750,$1000 ; 1250$ was non-significant between them. In opposite, to the low doses fertigation for (600 plus 750) recorded the lowest values through three tested seasons.

Potassium improves fruit length and finger diameter $(\mathrm{cm})$ and increases the content of starch and sugar content (Bhargava et al., 1993). As well as, Pandey and Sinha (1999) who stated that the increase in weight of the hand, weight of the bunch and yield per hectare are due to sulphur present in the sulphate of potash which might be responsible for the formation of iron-sulphur protein in plants which might have a direct impact in activating the catalase and peroxidase enzymes. 
Table 8. Effect of $\mathrm{N}$ and $\mathrm{K}$ fertigation on finger length and finger diameter $(\mathrm{cm})$ of $\mathrm{Ziv}$ banana plants at (2016/2017, 2017/2018 and 208/2019 seasons)

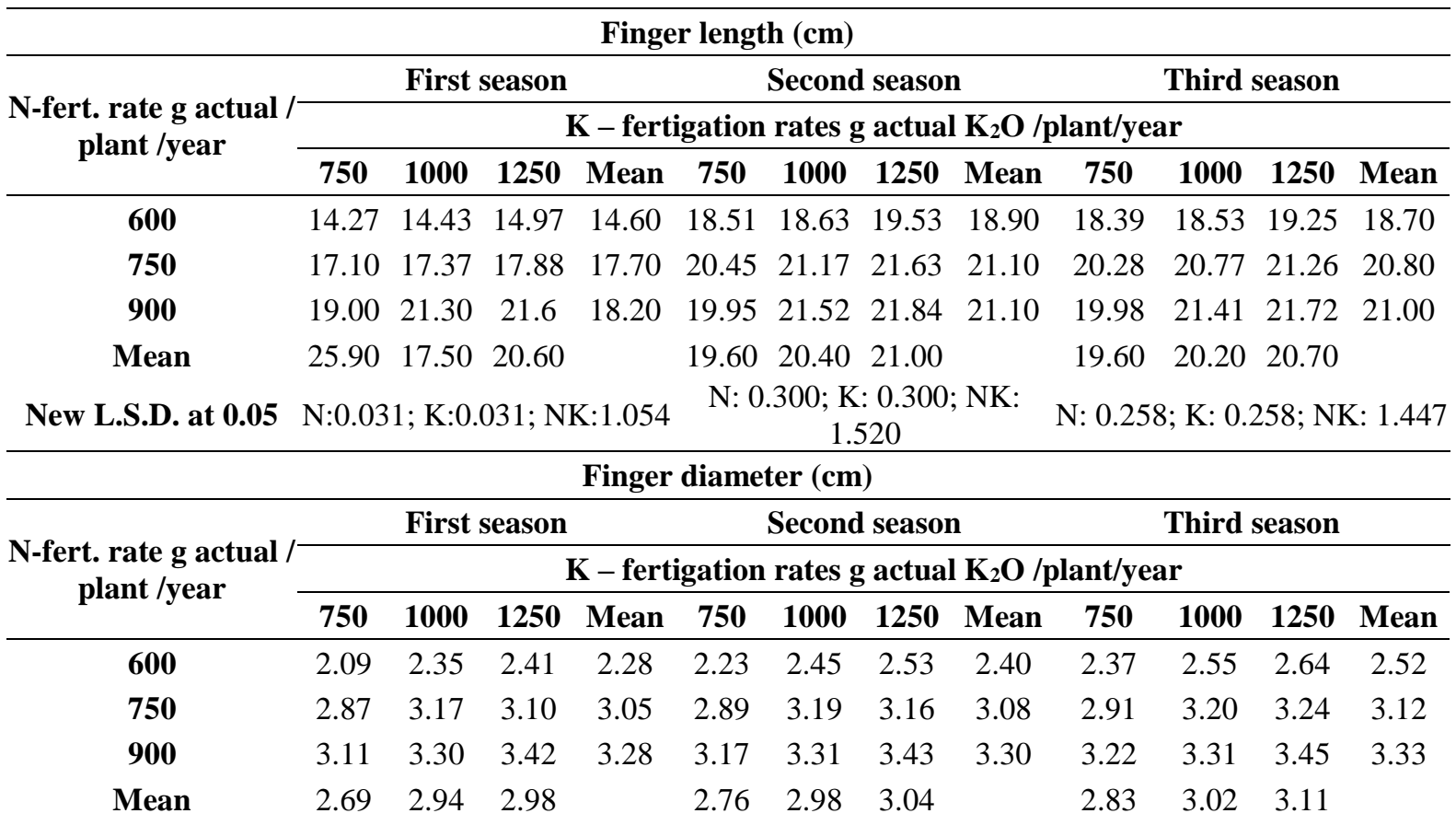

New L.S.D. at 0.05 N:0.115; K:0.115; NK: 0.199 N:0.097; K:0.097; NK:0.168 N:0.126; K:0.126; NK: 0.219

\section{Economic return}

The economic return of Ziv banana plants (Table 9) showed that net income gradually increase by increasing NK fertilizers. Plants were fertilized with the $900 \mathrm{~g} . \mathrm{N}+1250 \mathrm{~g} . \mathrm{K}_{2} \mathrm{O} /$ plant/year gave the highest income (221199 L.E./fed/year) compared with other treatment. While the lowest rate of $\mathrm{NK}$ fertilizer $\left(600 \mathrm{gN}+750 \mathrm{~g}\right.$. $\mathrm{k}_{2} \mathrm{O}$ plant/year $)$ gave the cheap income (75240 L.E./fed./year).

Table 9. Effect of $\mathrm{N}$ and $\mathrm{K}$ fertigation on net-return of $\mathrm{Ziv}$ banana plants

\begin{tabular}{|c|c|c|c|c|c|c|c|}
\hline \multirow{2}{*}{$\begin{array}{c}\text { Treatment(g) } \\
\text { Actual/plant/year }\end{array}$} & \multicolumn{3}{|c|}{ Cost of fertilizers (pound) } & \multirow{2}{*}{$\begin{array}{c}\text { Cost of } \\
\text { pesticides } \\
\text { (pound) }\end{array}$} & \multirow[b]{2}{*}{ Total } & \multirow{2}{*}{$\begin{array}{c}\text { Yield } \\
\text { price } \\
\text { (pound) }\end{array}$} & \multirow{2}{*}{$\begin{array}{c}\text { Net - } \\
\text { income } \\
\text { (pound) }\end{array}$} \\
\hline & $\begin{array}{l}\mathrm{NH}_{4} \mathrm{NO}_{3} \\
\text { (ton) }\end{array}$ & $\begin{array}{c}\mathrm{K}_{2 \mathrm{SO}} \\
\text { (ton) }\end{array}$ & $\begin{array}{c}\text { Other } \\
\text { fertilizer }\end{array}$ & & & & \\
\hline $600 \mathrm{~N}+750 \mathrm{~K}_{2} \mathrm{O}$ & 7360 & 15750 & 13050 & 2000 & 38160 & 113400 & 75240 \\
\hline $600 \mathrm{~N}+1000 \mathrm{~K}_{2} \mathrm{O}$ & 7360 & 21000 & 13050 & 2000 & 43410 & 142200 & 98790 \\
\hline $600 \mathrm{~N}+1250 \mathrm{~K}_{2} \mathrm{O}$ & 7360 & 26250 & 13050 & 2000 & 48660 & 165600 & 116940 \\
\hline $750 \mathrm{~N}+750 \mathrm{~K}_{2} \mathrm{O}$ & 10580 & 15750 & 13050 & 2000 & 41380 & 169200 & 127820 \\
\hline $750 \mathrm{~N}+1000 \mathrm{~K}_{2} \mathrm{O}$ & 10580 & 21000 & 13050 & 2000 & 46630 & 187200 & 140570 \\
\hline $750 \mathrm{~N}+1250 \mathrm{~K}_{2} \mathrm{O}$ & 10580 & 26250 & 13050 & 2000 & 51880 & 201600 & 149720 \\
\hline $900 \mathrm{~N}+750 \mathrm{~K}_{2} \mathrm{O}$ & 11500 & 15750 & 13050 & 2000 & 42300 & 201600 & 159300 \\
\hline $900 \mathrm{~N}+1000 \mathrm{~K}_{2} \mathrm{O}$ & 11500 & 21000 & 13050 & 2000 & 47550 & 219600 & 172050 \\
\hline $900 \mathrm{~N}+1250 \mathrm{~K}_{2} \mathrm{O}$ & 11500 & 26250 & 13050 & 2000 & 52800 & 273999 & 221199 \\
\hline
\end{tabular}

\section{Conclusion}

From the aforementioned results, it can be concluded that, both treatments of (1000 and 1250 $\left.\mathrm{K}_{2} \mathrm{O}\right)$ K-fertigation rates $(\mathrm{gm})$ and $(750$ and 900 $\mathrm{NH}_{4} \mathrm{NO}_{3}$ ) $\mathrm{N}$-fertigation rate gm/plant/year were the more effective and increasing growth, fruiting and fruit quality improving leaf nutrient contents, Nefficiency, K- efficiency as well as economic return of "Ziv" banana plants. On the other world from observed results we could be concluded to fertilized Ziv banana plants with $900 \mathrm{~g}$ actual $\mathrm{N}$ plant /year and $1250 \mathrm{~g} \mathrm{~K}_{2} \mathrm{O}$ actual /plant/year produced highest yield and highly economic return. 


\section{REFERENCES}

Amin, O.A.; Abd-El-Gawad, N.M.A.; Emam, H.E. and Abd El- Moneim, E.A.A. (2016). Effect of Soil Application with Humic and Amino acid on Vegetative Growth, Nutritional Statues, Yield and Fruit Quality of Grande Naine Banana Plants. Intern. J. Pharm-Tech. Res., 9(12): 88-96.

Bhargava, B.S.; Singh. H.P. and Chadha, L. (1993). Role of potassium in development of fruit quality. In: Adv. Hort., 2: 947-960.

Chapman, H.D. and Pratt, P.F. (1964). Methods of analysis for soils. Plant and Water. Div. Agric. Sci. Univ., California U.S.A. 150 p.

Edson S. N; Francine, L.C.; Erval, R.D.; Eduardo, J.F. and Ana L. B. (2017). Fertilization with nitrogen and potassium in banana cultivars 'Grand Naine', 'FHIA 17' and 'Nanicão IAC 2001' cultivated in Ribeira Valley, São Paulo State, Brazil. Acta Scientiarum. Agronomy Maringá, 39(4): 505-513.

Farias, H.C.; Donato, S.L.R.; Pereira, M.C.T. and Silva, S.O. (2010). Avaliação fitotécnica de bananeiras tipo terra sob irrigação em condições semi-áridas. Ciência e Agrotecnologia, 34(4): 380-386.

Geetha, K. (1998). Integrated plant nutrition system (IPNS) for maximizing yield in banana, Musa (AAB group) 'Nendran'. Ph. D thesis, Kerala Agricultural University, Thrissur, p. 149.

Hewitt, C. W. (1955). Leaf analysis as a guide to nutrition of banana. Emp. J. Exp. Agric., 23:11- 16 (C.F. Hort. Abst. 31:4346).

Hosny, S. S. (2010). Physiological studies on nutrition of banana plants. Thesis, Ph.D. Cairo university.

Ibrahim, E.G. (1993). Studies on irrigation of banana $\mathrm{Ph}$. D. Thesis, Fac. Agric. Zagazic Univ.

Ibrahim, E.G. (2003). The effect of fertigation with nitrogen and potassium nutrients on "Williams Egypt" banana grown and productivity in newly reclaimed soil. Egypt. J. Appl. Sci., 18 (11): 278-293.

Indira, M. and Nair, S. (2008). Standardization of NPK requirement in banana cv. "Njalipoovan" (Musa AB group) in Onattukara soil of South Kerala. J. Hortl. Sci., 3(2): 127-131.

Infana, N.M.; Sanaulla N. and Barkat A. (2015). Economic efficiency of banana production under contract farming in Sindk Pakistan. J. Clop. Economics, 3 (4): 2-5.

Jaime.T.B.; Jaiver D.S. and Danial, G.C.S. (2017), Nutrient accumulation models in the banana (Musa $A A A$ Simoonds cv. Williams) plant under nitrogen doses. Acta Agron., 66(3): 391-396.
Jothimani, P.; Sangeetha, R.; Kavitha, B. and Senthilraja, K. (2013). Effect of compost on growth and yield of Banana. Inter. J. Advanced Life Sci., 6(3): 131-138

Kumar, A. R. and Kumar, N. (2008 b). Potassium nutrition in banana. The Asian J. Hort., 3(2): 479482.

Kumar, A.R. and Kumar, N. (2008 a). Studies on the efficacy of sulphate of potash (SOP) on the physiological, yield and quality parameters of banana cv. Robusta (Cavendish-AAA). Eur. Asia J. Bio Sci., 2 (12): 102-109.

Loredana, L.; Catello, P.; Donatella, A.; Giuseppe, C.; Massimo, Z. and Marisa, D. (2015). Compost and compost tea management of mini watermelon cultivations affects the chemical, physical and sensory assessment of the fruits. Agric. Sci., 6: 117-125.

Moreira, R. S. (1999). Banana: teoria e prática de cultivo (2aed., CD ROM). Campinas, SP: Fundação Cargill.

Murry, D.B. (1960). Deficiency symptoms of the major elements in the banana. Trop. Agric. Trim. 36:100- 107. National campaign for improving banana productivity in Egypt, 2014. (In Arabi)

Pandey, S.N. and Sinha B.K. (1999). Plant physiology. Vikas Publishing House Private Limited, New Delhi; 1999

Pregl, F. (1945). Quantitative organic micro analysis, I.A. $4^{\text {th }}$ Ed., P. 17 Churchill, Ltd., London.176 p.

Snedecor, G.W. and Cochran, W.G. (1990). "Statistical Methods". 7 ${ }^{\text {th }}$ Ed., Iowa State Univ. Press Amer. Iowa, USA.

Soto-Ballestero, M. (2008). Bananos: técnicas de produción, poscosecha y comercialización $\left(3^{\text {rd }}\right.$ ed., CDROM). San José, CR: Litografía e Imprenta Lil. Teixeira.

Waller, P.A. and D.B. Duncan (1969). A buys rule for the symmetric multiple comparison problem. Amer. State Assoc. J., 64: 1484-1503.

Wenli, Li., Min, Y., Jie, W., Zhichao, W., Zihan, F., Furong, K., Yuheng, W., Yayin, L.; Dejiao, K.; Zhihui, C.; Chaoyi, G.; Yujia, Li.; Xinhua, He.; Xinping, C. and Yueqiang, Zh. (2020). Agronomic Responses of Major Fruit Crops to Fertilization in China: A Meta-Analysis. Agronomy, 10(1): 15-18.

Wilde, S. A.; Corey, R. B.; Layer, J. G. and Voigt, G. K. (1985). Soils and Plant Analysis for Tree Culture. $3^{\text {rd }}$ Ed. Oxford and IBH publishing Co., New Delhi, India, 529 - 546 pp. 